\title{
Physical Assessment Skills Performing Hurdles Among Nursing Students
}

Shaista Kausar, Lahore School of Nursing, The University of Lahore, PO box 54000, Lahore, Pakistan

Email: shaistakausar715@gmail.com; Mobile: 0320-0464715, ORCID: http://orcid.org/0000-0003-3580-5047

Muhammad Hussain, Lahore School of Nursing, the University of Lahore, PO box 54000, Lahore, Pakistan

E-mail:Muhammad.Hussain@Isn.uol.edu.pk

Mobile:0300-2105089.

Muhammad Afzal, Lahore School of Nursing, the University of Lahore, PO box 54000, Lahore, Pakistan.

Email:Muhammad.Afzal@Isn.uol.edu.pk

Mobile:0333-2186533

Syed Amir Gilani, FAHS the University of Lahore, PO box 54000, Lahore, Pakistan. Email: profgilani@gamil.com

Mobile:+92 (0)42 35321761, (+92) 42 111-865-865

Corresponding author: Shaista Kausar, The University of Lahore, Pakistan 1 - KM Defense Road, Lahore.

Tel: +92 (0)42 111-865-865; +92(0)4235321; Fax: +924235321761

Mobile phone: $\mathbf{9 2 0 3 2 0 0 4 6 4 7 1 5}$

E-mail: shaistakausar715@gmail.com

Received: 5/1/2020 Accepted: $25 / 2 / 2020$ Published: $1^{\text {st }}$ May, 2020

\section{Abstract}

Background: Physical assessment skills are an essential part of the nursing profession including inspection, auscultation, percussion, and palpation. Understanding hurdles to physical assessment among nursing students create a more detailed assessment in the development of quality patient care in nursing practice. This study examined the physical assessment skills performing hurdles among nursing students. Purpose: The purpose of the study is to assess the physical assessment skills performing hurdles among nursing students at Lahore School of Nursing, The University of Lahore. 
Methods: A quantitative descriptive cross-sectional study design was used to collect data from 103 nursing students. A convenient sampling method was used for this study. The questionnaire composed of 7 subscales in evaluating the physical assessment skills performing hurdles among nursing students between the classroom and clinical setting. A paired t-test was also used in determining the differences between physical assessment skills performing hurdles among nursing students in the classroom and clinical setting.

Results: The statistical differences between physical assessment skills performing hurdles among nursing students between classroom settings and clinical settings. Subscale "reliance on others and technology" $(p=.867)$, "Lack of time and interruptions" $(p=.733)$, "ward culture" $(\mathrm{p}=.032)$, "Lack of confidence" $(\mathrm{p}=.300)$, "Lack of nursing role models" ( $\mathrm{p}=.063)$, "lack of influence on patient care" ( $\mathrm{p}$ $=.088)$, "Specialty area" $(\mathrm{p}=.015)$, have significant differences in physical assessment skills performing hurdles among nursing students in classroom settings and clinical settings.

Conclusion: Although nursing students were oriented and educated about physical assessment skills as an integral part of the nursing curriculum, not often practiced in clinical settings. Reliance on others and technology, ward culture, lack of influence on patient care are hurdles in performing physical assessment skills. In addition, increasing self-confidence is vital to assess the patient's health status effectively and minimize the hurdles in performing the physical assessment skills.

\section{Keywords: Physical assessment skills, Nursing students, Clinical settings, Classroom settings.}

\section{Introduction}

Assessment is the first step in the nursing practice, and it is also an important part of the nursing skills. Nurses can perform an assessment in achieving better outcomes. For a nurse, it is important to teach about the physical assessment skills to provide better quality care [1].

Physical assessment skills are an essential part of the nursing profession including inspection, auscultation, percussion, and palpation. It requires a level of competence that motivate nursing students to gain knowledge and practice from an academic institution. And in the clinical area, it is also important for the quality of patient 
care. However, this competency level in the physical assessment skills was focused during the lecture as it underlined the improvement of skills in the clinical area [2]. To improve the quality of nursing student's knowledge and learning it is necessary to evaluate the hurdles which influence the nursing students learning and on their professional growth [3].

Taking history from the patient is one of the important steps of physical assessment [4]. The nurse should start the physical examination by creating a proper environment to ensure the privacy, comfort, and dignity of the patient [5]. If the health history advises examination on a particular area of the body, then the assessment will be carried out.

Physical assessment skills which show that the performance of skills in the educational setting. The most important hurdles during performing physical assessment skills are poor knowledge, lack of confidence level [6].

Nursing practice is established on the belief that the physical assessment skills would improve the patient's outcomes [7]. This statement applies to nurses in all settings. It is not just for who have experience in the physical examination skills. Though, specialization in physical assessment skills supported the research. The use of advanced physical assessment is apprehensive as nursing experience increase [8]. This level of education does not appear the impact of nursing skills [9].

Nursing students are facing a series of challenges progressively in clinical practices as well as in the education system. The influence of these challenges is on their learning skills. Therefore, lack of implementation nursing process in the training period is one of the major problems in the clinical area [3].

The use of modern technology in physical assessment skills results in low confidence in the clinical experience and exam. More reliance on laboratory results creates many issues that are a major risk for patient safety. However, due to this technology these skills require continuous progress which is necessary for the health care practitioner $[2]$.

The factor that affects the physical assessment skills is the lack of time due to increased work and more paperwork in the clinical setting and also in the classroom setting which affects the nursing performance towards skills. Less time at the bedside and for better 
care of patients distracts the nurse to perform skills on the patients [10].

Ward culture is another hurdles that affects the performance of physical assessment skills. Physical assessment skills perform in a certain area of the ward and require help from the coworker. Less time to the bedside as nurses gain more roles and responsibility can affect the skills [11].

Factors affect the physical assessment skills including lack of confidence to perform skills. It is reported that low confidence is a hurdle in conducting physical assessment skills that affects the nursing student's performance in the classroom as well as in the clinical area. These factors include a lack of confidence and lack of time that impact the assessment on the delivery of patients care [12]. The study revealed that nursing students have a low level of stress and competency as nursing skills [13].

Nursing performs its role and responsibility for the improvement of patient quality care. Lack of nursing role models is a hurdle that affects physical assessment skills. Nursing performs physical assessment skills within the clinical setting with the help of the health care practitioner. This increased the confidence level of the nurse during the assessment and help to discover new role models [14].

Factors that affect the nursing students during physical assessment skills, including lack of time, and lack of support from others. Nursing considers that physical assessment is not the responsibility of nurses. One study revealed that several barriers affect nurses during physical assessment skills in a clinical setting, including lack of influence on patient care and lack of nursing role models [2].

Another factor that affects the performance of physical assessment skills during clinical is the special area. Nurses have knowledge regarding the skills performing in the clinical setting. And don't perform these skills outside the specialty area, professional restrictions, clinical areas, and ward environment affecting the physical skills [7].

\section{Problem statement}

There are many factors that affect the physical assessment skills among nursing students as discussed above in the introduction. The problem is the lack of knowledge regarding these factors in nursing students. If this issue is not addressed, it can lead to many 
threats. Physical assessment skills performing hurdles will lead to a low confidence level among nursing students. If the nursing student's clinical performance is low, there will be low patient's quality care in the practical performance in the future. This will lead to poor quality patient care.

\section{Research question}

What are the physical assessment skills performing hurdles among nursing students?

\section{Significance}

The significance of the study help nursing students to improve their physical assessment skills. Physical examination skills benefits the patient'outcomes, the complexity of theactual nursing practice and leave their purpose ambiguous for most nursing situations.

This research is very helpful for students because physical assessment will increase confidence levels among nursing students. This potentially increase the competency level among nursing students. Nursing education is constantly struggling for the competence-based curricula in the preparation of students in the nursing profession.

\section{Methodology}

Study design

A quantitative descriptive cross-sectional study design used to collect data from nursing students.

\section{Study Setting}

The study was carried out at Lahore School of Nursing, The University of Lahore, Pakistan.

\section{Sample size}

Slovin's sampling formula used to find the sample size of the study population.

$$
\mathrm{n}=\mathrm{N} / \mathbf{1}+(\mathbf{N})(\mathrm{E})^{2}
$$

Where $\mathrm{N}=$ =Population, $\quad \mathrm{n}=$ Sample size, $\quad \mathrm{E}=$ Margin of error

\section{Sampling Method}

A convenient sampling method used for this study.

\section{Inclusion Criteria}

The students of department The Lahore School of Nursing 4 Years Bachelor of Science in Nursing, semester IV, semester VI and semester VIII included in this study. Both male and female nursing 
students included in this study. The age of the participants were between 18 to 27 years.

\section{Exclusion Criteria}

Four years Bachelor of Science in Nursing, Year I, Semester II are not included in this study. Students from all other departments are excluded from the study.

\section{Research tool}

As well-structured questioner with a close-ended, Likert scale adopted to assess the physical assessment skills performing hurdles among nursing students. The questionnaire consisted of two portions the first portion explains the demographic data of students in which name, age, gender, etc., and the second part of the questionnaire will explain the 36 questions composed of 7 subscales in evaluating the physical assessment skills performing hurdles, 7 subscales on Likert scale. The scale content validity index was 0.92 , and the coefficient alpha for the total 38 -item scale was 0.80 , respectively.

\section{Data Analysis}

Data analyzed by SPSS version 21. The study is descriptive and all the descriptive statistics obtained through the SPSS software.

\section{Ethical consideration}

Permission has been taken from the HOD of Lahore School of Nursing department for conduct this research. The informed consent form has signed before data collection from all the participants. All information and data collection kept confidential.

\section{Results}

Table 1 shows that $53(51.5 \%)$ participant have the age bracket from 18-21 years old which is the highest age bracket, 48 (46.6\%) have age group 21-24 years old and $02(1.9 \%)$ have $24-27$ years old. Most of the nursing students have a grade in physical assessment between $80 \%$ and $84 \%$ while 20 or $19.4 \%$ of the nursing students have a grade between $85 \%$ and $90 \%$ and only eight students have a grade $90-94 \%$ in physical assessment. Almost all the nursing students were regular students. There were 30 male nursing students and 73 female nursing students from the 103 participants. 50 (49\%) nursing students from the $4^{\text {th }}$ semester, $41(42 \%)$ from the $6^{\text {th }}$ semester and $13(7.8 \%)$ from the $8^{\text {th }}$ semester included in this study. 
Table 1: Socio-demographic characteristics of the nursing students

\begin{tabular}{|c|c|c|c|}
\hline $\begin{array}{l}\text { Sr. } \\
\text { No }\end{array}$ & Variables & Frequency & Percentage \\
\hline \multirow[t]{4}{*}{1} & Age & & \\
\hline & 18-21 years & 53 & $51.5 \%$ \\
\hline & 21-24 years & 48 & $46.6 \%$ \\
\hline & 24-27 years & 02 & $1.9 \%$ \\
\hline \multirow[t]{4}{*}{2} & $\begin{array}{l}\text { Grade in physical } \\
\text { assessment (theory or } \\
\text { practical average) }\end{array}$ & & \\
\hline & 90 to $94 \%(\mathrm{~A})$ & 8 & $7.8 \%$ \\
\hline & 85 to $90 \%(\mathrm{~B}+)$ & 20 & $19.4 \%$ \\
\hline & 80 to $84 \%(B)$ & 75 & $72.8 \%$ \\
\hline \multirow[t]{3}{*}{3} & Type of admission & & \\
\hline & Regular & 103 & $100 \%$ \\
\hline & Bridging & $\mathbf{0}$ & $0 \%$ \\
\hline \multirow[t]{3}{*}{4} & Gender & & \\
\hline & Male & 30 & $29.1 \%$ \\
\hline & Female & 73 & $70.9 \%$ \\
\hline \multirow[t]{4}{*}{5} & Level & & \\
\hline & Semester $4^{\text {th }}$ & 50 & $49 \%$ \\
\hline & Semester $6^{\text {th }}$ & 41 & $42 \%$ \\
\hline & Semester $8^{\text {th }}$ & 13 & $7.8 \%$ \\
\hline
\end{tabular}

Table 2: shows that $18.4 \%$ (19) nursing students agree that it's not the nurse's role to conduct a physical assessment of the patient. Almost 30.1\% (30) participants agree that they gather all the physical assessment data using electronic monitoring devices. Approximately $53.4 \%$ (55) participant agrees with the use of technology reduces the need for nurses' physical assessment skills. About 38.8\% (40) nursing students agree that nurses don't need to use many physical assessment skills to do their job well. Round about 36.9\% (38) nursing students agree that physical assessment is something only the doctor. About $57.3 \%$ (59) nursing students agree with relying on monitoring equipment to collect assessment data. Approximately 48.6\% (50) nursing students agree with physical assessment is used only when a 
patient deteriorates. Almost 62.1\% (64) nursing students agree with physical assessment is the responsibility of medical or allied health staff. About $42.7 \%$ (44) nursing students agree that they don't use physical assessment skills because of the task-oriented nature of the work. Almost 75.7\% (78) nursing students agree that lack of time is a barrier in using physical assessment skills. Round about 71.9\% (74) nursing students agree that lack of time to do an in-depth physical assessment to the patients. Approximately 72.8\% (75) nursing students agree that no time to use physical assessment skills because of the workload. Almost $73.8 \%$ (76) nursing students agree with completing checklists and documentation means no time to use physical assessment skills. About 76.7\% (79) nursing students agree that too many interruptions during work prevent them from doing the physical assessment. Almost 74.7\% (77) nursing students agree with that the ward culture is a barrier in using of physical assessment skills. Approximately $79.6 \%$ (82) nursing students agree that assessment is done a certain way in the ward which limits the extent of physical assessment. Almost $74.7 \%$ (77) nursing students agree that assessments I make using physical assessment skills are not valued by my coworkers. Around 80.6\% (83) nursing students agree that the ward culture discourages nurses from doing the physical assessment in my workplace. Almost $82.5 \%$ (85) nursing students agree that the feel of support by the colleagues to use physical assessment skills. Almost $80.6 \%$ (83) nursing students agree that the lack of confidence in accurately performing physical assessment skills. Round about $74.7 \%$ (77) nursing students agree that worrying about the ability to correctly use physical assessment skills. A 73.8\% (76) nursing students agree that lack of confidence in deciding what physical assessment skills to use. Relatively $73.8 \%$ (76) nursing students agree that competently use physical assessment skills. Approximately 83.5\% (86) nursing students agree that the physical assessment skills are role modeled by experienced nurses in the ward. About 78.7\% (81) nursing students agree that the nurse leaders promote the use of physical assessment skills in the unit. Almost $80.6 \%$ (83) nursing students agree that the nurses encourage each other to use physical assessment skills in the ward. A $75.7 \%$ (78) nursing students agree that there is a lack of experienced nursing staff to role model physical assessment skills in the ward. Approximately $79.7 \%$ (82) nursing students agree that the information using physical assessment skills is used to develop a plan 
of care. Relatively $83.5 \%$ (86) nursing students agree that the ability to use physical assessment skills makes a positive difference in patient care. Round about $77.7 \%$ (80) nursing students agree that the ability to use physical assessment skills improves the quality of nursing care. About $85.4 \%$ (88) nursing students agree that the information collected using physical assessment skills is used to make treatment decisions. About 76.7\% (79) nursing students agree that physical assessment skills are relevant to nurses in the specialty area. Almost $73.8 \%$ (76) nursing students agree that they don't use physical assessment skills that are outside of the specialty area. A $77.6 \%(80)$ nursing students agree that the specialty area determines the physical assessment skills that nurses used. About 76.7\% (79) nursing students agree that the physical assessment skills are restricted only specialty areas. Almost $77.7 \%$ (80) nursing students agree that the physical assessment skills determined by what is acceptable in the ward.

Table 3: shows that $0 \%(0)$ nursing students agree that it's not the nurse's role to conduct a physical assessment of the patient. About $38.8 \%$ (40) participants agree that they gather all the physical assessment data using electronic monitoring devices. A $58.2 \%$ (60) participant agrees with the use of technology reduces the need for nurses' physical assessment skills. Almost 59.2\% (61) nursing students agree that nurses don't need to use many physical assessment skills to do their job well. Approximately 49.5\% (51) nursing students agree that physical assessment is something only the doctor. Round about $39.8 \%$ (41) nursing students agree with relying on monitoring equipment to collect assessment data. A 59.2\% (61) nursing students agree with physical assessment is used only when a patient deteriorates. About $61.1 \%$ (63) nursing students agree with physical assessment is the responsibility of medical or allied health staff.

Relatively $41.7 \%$ (43) nursing students agree that they don't use physical assessment skills because of the task-oriented nature of the work. About $68.9 \%$ (71) nursing students agree that lack of time is a barrier in using physical assessment skills. Almost 78.6\% (81) nursing students agree that lack of time to do an in-depth physical assessment to the patients. A $78.6 \%$ (81) nursing students agree that no time to use physical assessment skills because of the workload. 
Table 2: Percentage of nursing student's respondents that agreed with each subscale item $(n=103)$ in the classroom setting

\begin{tabular}{|c|c|c|c|}
\hline $\begin{array}{l}\text { Sr. } \\
\text { No }\end{array}$ & Subscale & $\begin{aligned} \text { Agl } \\
\text { Strongly }\end{aligned}$ & e \\
\hline & $\begin{array}{l}\text { Subscale 1:Reliance on others and } \\
\text { technology }\end{array}$ & Frequency & Percent \\
\hline 1 & $\begin{array}{l}\text { It's not the nurse's role to conduct a } \\
\text { physical assessment of the patient. }\end{array}$ & 19 & 18.4 \\
\hline 2 & $\begin{array}{l}\text { Gather all the physical assessment } \\
\text { data using electronic monitoring } \\
\text { devices. }\end{array}$ & 31 & 30.1 \\
\hline 3 & $\begin{array}{l}\text { The use of technology reduces the } \\
\text { need for nurses' physical assessment } \\
\text { skills. }\end{array}$ & 55 & 53.4 \\
\hline 4 & $\begin{array}{l}\text { Nurses don't need to use many } \\
\text { physical assessment skills to do their } \\
\text { job well. }\end{array}$ & 40 & 38.8 \\
\hline 5 & $\begin{array}{l}\text { Physical assessment is something } \\
\text { only the doctor does. }\end{array}$ & 38 & 36.9 \\
\hline 6 & $\begin{array}{l}\text { Relying on monitoring equipment to } \\
\text { collect assessment data. }\end{array}$ & 59 & 57.3 \\
\hline 7 & $\begin{array}{l}\text { Physical assessment is used only } \\
\text { when a patient deteriorates. }\end{array}$ & 50 & 48.6 \\
\hline 8 & $\begin{array}{l}\text { Physical assessment is the } \\
\text { responsibility of medical or allied } \\
\text { health staff. }\end{array}$ & 64 & 62.1 \\
\hline 9 & $\begin{array}{l}\text { Don't use physical assessment skills } \\
\text { because of the task-oriented nature } \\
\text { of the work. }\end{array}$ & 44 & 42.7 \\
\hline & $\begin{array}{l}\text { Subscale 2:Lack of time and } \\
\text { interruptions }\end{array}$ & & \\
\hline 10 & $\begin{array}{l}\text { Lack of time is a barrier to using } \\
\text { physical assessment skills. }\end{array}$ & 78 & 75.7 \\
\hline 11 & $\begin{array}{l}\text { Lack of time to do an in-depth } \\
\text { physical assessment for the patients. }\end{array}$ & 74 & 71.9 \\
\hline
\end{tabular}


AAJMS \{Formerly IJMS],May, 2020;3(2):44-65; ISSNe 2522-7386

\begin{tabular}{|c|c|c|c|}
\hline 12 & $\begin{array}{l}\text { No time to use physical assessment } \\
\text { skills because of the workload. }\end{array}$ & 75 & 72.8 \\
\hline 13 & $\begin{array}{l}\text { Completing checklists and } \\
\text { documentation means no time to use } \\
\text { physical assessment skills. }\end{array}$ & 76 & 73.8 \\
\hline \multirow[t]{2}{*}{14} & $\begin{array}{l}\text { Too many interruptions during } \\
\text { work prevent from doing the } \\
\text { physical assessment. }\end{array}$ & 79 & 76.7 \\
\hline & Subscale 3:Ward culture & & \\
\hline 15 & $\begin{array}{l}\text { The ward culture is a barrier in } \\
\text { using of physical assessment skills. }\end{array}$ & 77 & 74.7 \\
\hline 16 & $\begin{array}{l}\text { Assessment is done a certain way in } \\
\text { the ward which limits the extent of } \\
\text { physical assessment. }\end{array}$ & 82 & 79.6 \\
\hline 17 & $\begin{array}{l}\text { Assessments I make using physical } \\
\text { assessment skills are not valued by } \\
\text { my coworkers. }\end{array}$ & 77 & 74.7 \\
\hline 18 & $\begin{array}{l}\text { The ward culture discourages } \\
\text { nurses from doing a physical } \\
\text { assessment in my workplace. }\end{array}$ & 83 & 80.6 \\
\hline \multirow[t]{2}{*}{19} & $\begin{array}{l}\text { Feel of support by the colleagues to } \\
\text { use physical assessment skills. }\end{array}$ & 85 & 82.5 \\
\hline & Subscale 4:Lack of confidence & & \\
\hline 20 & $\begin{array}{l}\text { Lack of confidence in accurately } \\
\text { performing physical assessment } \\
\text { skills. }\end{array}$ & 83 & 80.6 \\
\hline 21 & $\begin{array}{l}\text { Worrying about the ability to } \\
\text { correctly use physical assessment } \\
\text { skills. }\end{array}$ & 77 & 74.7 \\
\hline 22 & $\begin{array}{l}\text { Lack of confidence in deciding what } \\
\text { physical assessment skills to use. }\end{array}$ & 76 & 73.8 \\
\hline \multirow[t]{2}{*}{23} & $\begin{array}{l}\text { Competently use } \\
\text { assessment skills. }\end{array}$ & 76 & $\mathbf{7 3 . 8}$ \\
\hline & $\begin{array}{l}\text { Subscale 5:Lack of nursing role } \\
\text { models }\end{array}$ & & \\
\hline 24 & $\begin{array}{l}\text { Physical assessment skills are role } \\
\text { modeled by experienced nurses in } \\
\text { the ward. }\end{array}$ & 86 & 83.5 \\
\hline
\end{tabular}




\begin{tabular}{|c|c|c|c|}
\hline 25 & $\begin{array}{l}\text { Nurse leaders promote the use of } \\
\text { physical assessment skills in the } \\
\text { unit. }\end{array}$ & 81 & 78.7 \\
\hline 26 & $\begin{array}{l}\text { Nurses encourage each other to use } \\
\text { physical assessment skills in the } \\
\text { ward. }\end{array}$ & 83 & 80.6 \\
\hline \multirow[t]{2}{*}{27} & $\begin{array}{l}\text { There is a lack of experienced } \\
\text { nursing staff to role model physical } \\
\text { assessment skills in the ward. }\end{array}$ & 78 & $\mathbf{7 5 . 7}$ \\
\hline & $\begin{array}{l}\text { Subscale 6: Lack of influence on } \\
\text { patient care }\end{array}$ & & \\
\hline 28 & $\begin{array}{l}\text { Information using physical } \\
\text { assessment skills is used to develop a } \\
\text { plan of care. }\end{array}$ & 82 & 79.7 \\
\hline 29 & $\begin{array}{l}\text { The ability to use physical } \\
\text { assessment skills makes a positive } \\
\text { difference in patient care. }\end{array}$ & 86 & 83.5 \\
\hline 30 & $\begin{array}{l}\text { The ability to use physical } \\
\text { assessment skills improves the } \\
\text { quality of nursing care. }\end{array}$ & 80 & 77.7 \\
\hline \multirow[t]{2}{*}{31} & $\begin{array}{l}\text { The information collected using } \\
\text { physical assessment skills is used to } \\
\text { make treatment decisions. }\end{array}$ & 88 & 85.4 \\
\hline & Subscale 7:Specialty Area & & \\
\hline 32 & $\begin{array}{l}\text { Physical assessment skills are } \\
\text { relevant to nurses in the specialty } \\
\text { area. }\end{array}$ & 79 & 76.7 \\
\hline 33 & $\begin{array}{l}\text { Don't use physical assessment skills } \\
\text { that are outside of the specialty } \\
\text { area. }\end{array}$ & 76 & $\mathbf{7 3 . 8}$ \\
\hline 34 & $\begin{array}{l}\text { The specialty area determines the } \\
\text { physical assessment skills that } \\
\text { nurses used. }\end{array}$ & 80 & 77.6 \\
\hline 35 & $\begin{array}{l}\text { The physical assessment skills are } \\
\text { restricted to only specialty areas. }\end{array}$ & 79 & 76.7 \\
\hline 36 & $\begin{array}{l}\text { The physical assessment skills } \\
\text { determined by what is acceptable in } \\
\text { the ward. }\end{array}$ & 80 & 77.7 \\
\hline
\end{tabular}


Table 3: Percentage of nursing student's respondents that agreed with each subscale item $(n=103)$ in the clinical setting

\begin{tabular}{|c|c|c|c|}
\hline $\begin{array}{l}\text { Sr. } \\
\text { No }\end{array}$ & Subscale & \multicolumn{2}{|c|}{$\begin{array}{c}\text { Agree } \\
\text { Strongly Agree }\end{array}$} \\
\hline & $\begin{array}{l}\text { Subscale 1:Reliance on others and } \\
\text { technology }\end{array}$ & Frequency & Percent \\
\hline 1 & $\begin{array}{l}\text { It's not the nurse's role to conduct a } \\
\text { physical assessment of the patient. }\end{array}$ & $\mathbf{0}$ & $\mathbf{0}$ \\
\hline 2 & $\begin{array}{l}\text { Gather all the physical assessment } \\
\text { data using electronic monitoring } \\
\text { devices. }\end{array}$ & 40 & 38.8 \\
\hline 3 & $\begin{array}{l}\text { The use of technology reduces the } \\
\text { need for nurses' physical assessment } \\
\text { skills. }\end{array}$ & 60 & 58.2 \\
\hline 4 & $\begin{array}{l}\text { Nurses don't need to use many } \\
\text { physical assessment skills to do their } \\
\text { job well. }\end{array}$ & 61 & 59.2 \\
\hline 5 & $\begin{array}{l}\text { Physical assessment is something only } \\
\text { the doctor does. }\end{array}$ & 51 & 49.5 \\
\hline 6 & $\begin{array}{l}\text { Relying on monitoring equipment to } \\
\text { collect assessment data. }\end{array}$ & 41 & 39.8 \\
\hline 7 & $\begin{array}{l}\text { Physical assessment is used only when } \\
\text { a patient deteriorates. }\end{array}$ & 61 & 59.2 \\
\hline 8 & $\begin{array}{l}\text { Physical assessment is the } \\
\text { responsibility of medical or allied } \\
\text { health staff. }\end{array}$ & 63 & 61.1 \\
\hline \multirow[t]{2}{*}{9} & $\begin{array}{l}\text { Don't use physical assessment skills } \\
\text { because of the task-oriented nature of } \\
\text { the work. }\end{array}$ & 43 & 41.7 \\
\hline & $\begin{array}{l}\text { Subscale 2:Lack of time and } \\
\text { interruptions }\end{array}$ & & \\
\hline 10 & $\begin{array}{l}\text { Lack of time is a barrier to using } \\
\text { physical assessment skills. }\end{array}$ & 71 & 68.9 \\
\hline 11 & $\begin{array}{l}\text { Lack of time to do an in-depth } \\
\text { physical assessment for the patients. }\end{array}$ & 81 & 78.6 \\
\hline 12 & No time to use physical assessment & 81 & 78.6 \\
\hline
\end{tabular}


AAJMS \{Formerly IJMS],May, 2020;3(2):44-65; ISSNe 2522-7386

\begin{tabular}{|c|c|c|c|}
\hline & skills because of the workload. & & \\
\hline 13 & $\begin{array}{l}\text { Completing checklists and } \\
\text { documentation means no time to use } \\
\text { physical assessment skills. }\end{array}$ & 61 & 59.2 \\
\hline \multirow[t]{2}{*}{14} & $\begin{array}{l}\text { Too many interruptions during work } \\
\text { prevent from doing the physical } \\
\text { assessment. }\end{array}$ & 71 & 68.9 \\
\hline & Subscale 3:Ward culture & & \\
\hline 15 & $\begin{array}{l}\text { The ward culture is a barrier in using } \\
\text { of physical assessment skills. }\end{array}$ & 61 & 59.2 \\
\hline 16 & $\begin{array}{l}\text { Assessment is done a certain way in } \\
\text { the ward which limits the extent of } \\
\text { physical assessment. }\end{array}$ & 50 & 48.5 \\
\hline 17 & $\begin{array}{l}\text { Assessments I make using physical } \\
\text { assessment skills are not valued by } \\
\text { my coworkers. }\end{array}$ & 31 & 30.1 \\
\hline 18 & $\begin{array}{l}\text { The ward culture discourages nurses } \\
\text { from doing the physical assessment in } \\
\text { my workplace. }\end{array}$ & 61 & 59.2 \\
\hline \multirow[t]{2}{*}{19} & $\begin{array}{l}\text { Feel of support by the colleagues to } \\
\text { use physical assessment skills. }\end{array}$ & 61 & 59.2 \\
\hline & Subscale 4:Lack of confidence & & \\
\hline 20 & 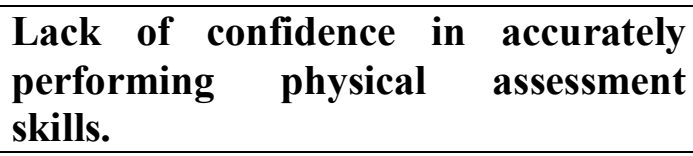 & 81 & 78.6 \\
\hline 21 & $\begin{array}{l}\text { Worrying about the ability to } \\
\text { correctly use physical assessment } \\
\text { skills. }\end{array}$ & 81 & 78.6 \\
\hline 22 & $\begin{array}{l}\text { Lack of confidence in deciding what } \\
\text { physical assessment skills to use. }\end{array}$ & 50 & 48.5 \\
\hline \multirow[t]{2}{*}{23} & $\begin{array}{l}\text { Competently use physical assessment } \\
\text { skills. }\end{array}$ & 43 & 41.7 \\
\hline & $\begin{array}{l}\begin{array}{l}\text { Subscale 5:Lack of nursing role } \\
\text { models }\end{array} \\
\end{array}$ & & \\
\hline 24 & $\begin{array}{l}\text { Physical assessment skills are role } \\
\text { modeled by experienced nurses in the } \\
\text { ward. }\end{array}$ & 71 & 68.9 \\
\hline 25 & Nurse leaders promote the use of & 60 & 58.2 \\
\hline
\end{tabular}


AAJMS \{Formerly IJMS],May, 2020;3(2):44-65; ISSNe 2522-7386

\begin{tabular}{|c|c|c|c|}
\hline & physical assessment skills in the unit. & & \\
\hline 26 & $\begin{array}{l}\text { Nurses encourage each other to use } \\
\text { physical assessment skills in the } \\
\text { ward. }\end{array}$ & 71 & 68.9 \\
\hline \multirow[t]{2}{*}{27} & $\begin{array}{l}\text { There is a lack of experienced } \\
\text { nursing staff to role model physical } \\
\text { assessment skills in the ward. }\end{array}$ & 53 & $\mathbf{5 1 . 5}$ \\
\hline & $\begin{array}{l}\text { Subscale 6:Lack of influence on } \\
\text { patient care }\end{array}$ & & \\
\hline 28 & $\begin{array}{l}\text { Information using physical } \\
\text { assessment skills is used to develop a } \\
\text { plan of care. }\end{array}$ & 51 & 49.5 \\
\hline 29 & $\begin{array}{l}\text { The ability to use physical assessment } \\
\text { skills makes a positive difference in } \\
\text { patient care. }\end{array}$ & 81 & 78.6 \\
\hline 30 & $\begin{array}{l}\text { The ability to use physical assessment } \\
\text { skills improves the quality of nursing } \\
\text { care. }\end{array}$ & 51 & 49.5 \\
\hline \multirow[t]{2}{*}{31} & $\begin{array}{l}\text { The information collected using } \\
\text { physical assessment skills is used to } \\
\text { make treatment decisions. }\end{array}$ & 63 & 61.1 \\
\hline & Subscale 7:Specialty Area & & \\
\hline 32 & $\begin{array}{l}\text { Physical assessment skills are } \\
\text { relevant to nurses in the specialty } \\
\text { area. }\end{array}$ & 53 & $\mathbf{5 1 . 5}$ \\
\hline 33 & $\begin{array}{l}\text { Don't use physical assessment skills } \\
\text { that are outside of the specialty area. }\end{array}$ & 63 & 61.2 \\
\hline 34 & $\begin{array}{l}\text { The specialty area determines the } \\
\text { physical assessment skills that nurses } \\
\text { used. }\end{array}$ & 31 & 30.1 \\
\hline 35 & $\begin{array}{l}\text { The physical assessment skills are } \\
\text { restricted to only specialty areas. }\end{array}$ & 52 & 50.5 \\
\hline 36 & $\begin{array}{l}\text { The physical assessment skills } \\
\text { determined by what is acceptable in } \\
\text { the ward. }\end{array}$ & 33 & 32 \\
\hline
\end{tabular}


Approximately 59.2\% (61) nursing students agree with completing checklists and documentation means no time to use physical assessment skills. About $68.9 \%$ (71) nursing students agree that too many interruptions during the work prevent them from doing a physical assessment. Around 59.2\% (61) nursing students agree that the ward culture is a barrier in using of physical assessment skills. A $48.5 \%$ (50) nursing students agree that assessment is done a certain way in the ward which limits the extent of physical assessment. Around 30.1\% (31) nursing students agree that assessments I make using physical assessment skills are not valued by my coworkers. About 59.2\% (61) nursing students agree that the ward culture discourages nurses from doing a physical assessments in my workplace. Relatively $59.2 \%$ (61) nursing students agree that the feel of support by the colleagues to use physical assessment skills. Approximately $78.6 \%$ (81) nursing students agree that the lack of confidence in accurately performing physical assessment skills. A $78.6 \%$ (81) nursing students agree with that worrying about the ability to correctly use physical assessment skills. About 48.5\% (50) nursing students agree that lack of confidence in deciding what physical assessment skills to use. Round about $41.7 \%$ (43) nursing students agree that competently use physical assessment skills. About $68.9 \%$ (71) nursing students agree that the physical assessment skills are role modeled by experienced nurses in the ward. Almost 58.2\% (60) nursing students agree that the nurse leaders promote the use of physical assessment skills in the unit. A $68.9 \%$ (71) nursing students agree that the nurses encourage each other to use physical assessment skills in the ward. About 51.5\% (53) nursing students agree that there is a lack of experienced nursing staff to role model physical assessment skills in the ward. Almost 49.5\% (51) nursing students agree with that the information using physical assessment skills is used to develop a plan of care. Approximately $78.6 \%$ (81) nursing students agree with that the ability to use physical assessment skills makes a positive difference in patient care. About $49.5 \%$ (51) nursing students agree that the ability to use physical assessment skills improves the quality of nursing care. A $61.1 \%$ (63) nursing students agree that the information collected using physical assessment skills is used to make treatment decisions. Almost 51.5\% (53) nursing students agree that physical assessment skills are relevant to nurses in the specialty areas. Relatively $61.2 \%$ (63) nursing students agree that they 
don't use physical assessment skills that are outside of the specialty area. About 30.1\% (31) nursing students agree that the specialty area determines the physical assessment skills that nurses used. A 50.5\% (52) nursing students agree that the physical assessment skills are restricted only specialty areas. Approximately 32\% (33) nursing students agree that the physical assessment skills determined by what is acceptable in the ward.

Table 4: The difference on hurdles in physical assessment in a different learning setting

\begin{tabular}{|c|c|c|c|c|c|}
\hline \multirow[b]{2}{*}{ Subscale } & \multicolumn{2}{|c|}{ Learning Setting } & \multirow[b]{2}{*}{$\begin{array}{c}\text { Mean } \\
\text { difference }\end{array}$} & \multirow[b]{2}{*}{$\mathbf{t}$} & \multirow[b]{2}{*}{$\mathbf{P}$} \\
\hline & $\begin{array}{c}\text { Classroom } \\
\text { mean }\end{array}$ & $\begin{array}{c}\text { Clinical } \\
\text { mean }\end{array}$ & & & \\
\hline $\begin{array}{lr}\text { Reliance on } \\
\text { others and } \\
\text { technology }\end{array}$ & 3.07 & 3.05 & 0.02 & -.173 & .867 \\
\hline $\begin{array}{l}\text { Lack of time } \\
\text { and } \\
\text { interruptions }\end{array}$ & 3.91 & 3.96 & -0.05 & .366 & .733 \\
\hline Ward culture & 3.99 & 3.51 & 0.48 & -3.223 & .032 \\
\hline $\begin{array}{ll}\text { Lack } \\
\text { confidence }\end{array}$ & 3.99 & 3.68 & 0.31 & -1.249 & .300 \\
\hline $\begin{array}{lr}\text { Lack } & \text { of } \\
\text { nursing } & \text { role } \\
\text { models } & \\
\end{array}$ & 4.11 & 3.82 & 0.29 & -2.881 & .063 \\
\hline $\begin{array}{l}\text { Lack of } \\
\text { influence on } \\
\text { patient care }\end{array}$ & 4.06 & 3.67 & 0.39 & -2.492 & .088 \\
\hline Specialty area & 3.98 & 3.25 & 0.73 & -4.075 & .015 \\
\hline
\end{tabular}

As mentioned in Tables 2 and 3, the statistical differences between physical assessment skills performing hurdles among nursing students between classroom settings and clinical settings. Subscale "reliance on others and technology" $(\mathrm{P}=.867)$, "Lack of time and interruptions" $(\mathrm{P}=.733)$, "ward culture" $(\mathrm{P}=.032)$, "Lack of confidence" $(\mathrm{P}=.300)$, "Lack of nursing role models" $(\mathrm{P}=.063)$, "lack of influence on patient care" $(\mathrm{P}=.088)$, "Specialty area" ( $\mathrm{P}$ 
$=.015$ ), have significant differences in physical assessment skills performing hurdles among nursing students in classroom settings and clinical settings.

\section{Discussion}

This study focused on nursing student's responses to physical assessment skills performing hurdles between the classroom settings and clinical settings. In demographic data, age of all participant from 18-27 years that are mostly female. A similar study conducted in the Lahore School of Nursing has the similar results that mostly participant was female [15]. About 77.7\% (80) nursing students agree that the ability to use physical assessment skills improves the quality of nursing care. A similar study conducted in 2019 that indicate that $64.9 \%$ of responding nurses agreed or agreed that information technology improved the quality of patient care and give nurses more time to practice care nursing [16]. In this study, results show that $78.6 \%$ (81) nursing students agree that the lack of confidence in accurately performing physical assessment skills. Approximately $68.9 \%$ (71) nursing students agree that the physical assessment skills are role modeled by experienced nurses in the ward. Another study revealed that physical assessment skills which show that the performance of skills in the educational setting. The most important hurdles during performing physical assessment skills are poor knowledge, lack of confidence level and no time at the bed-side.

Nurses who understood the need for physical assessment skills learned through practice had a willingness to use these skills in the nursing practice [6]. In this study $83.5 \%$ (86) nursing students agree that the ability to use physical assessment skills makes a positive difference to patient care. Almost $85.4 \%$ (88) nursing students agree that the information collected using physical assessment skills is used to make treatment decisions. Another study revealed that the physical assessment skills were improved by the educational program and performing physical assessment skills. It is compulsory to start a continuing education program to improve nurses' physical assessment skills and improve patient quality care [6]. In this study $78.6 \%(81)$ nursing students agree that the ability to use physical assessment skills makes a positive difference to patient care. About $49.5 \%$ (51) nursing students agree that the ability to use physical assessment skills improves the quality of nursing care. About 61.1\% (63) nursing students agree that the information collected using physical 
assessment skills is used to make treatment decisions. Another study stated that physical assessment is important to deliver good quality care and outcomes. It is necessary for the nurse to prepare and trained before performing the assessment. Support need to perform an assessment with appropriate equipment to provide the best quality care [17]. In this study $59.2 \%$ (61) nursing students agree that the ward culture discourages nurses from doing the physical assessment in my workplace. Approximately 59.2\% (61) nursing students agree that the feel of support by the colleagues to use physical assessment skills. Other studies conclude that students who suppose that their knowledge is based on comprehension will be more comfortable in performing skill task and will be scored with a higher level of performance skills. Researchers are unable to conclude why nursing students from certain colleges considerably higher their knowledge and skills than students from other colleges [18]. In this study $49.5 \%$ (51) nursing students agree that the information using physical assessment skills is used to develop a plan of care. Almost $78.6 \%$ (81) nursing students agree that the ability to use physical assessment skills makes a positive difference in patient care. The other study showed that physical examination by taking a history of health in an order of inspection, palpation, percussion and auscultation from different part of the body in a head-to-toe manner which gives the accurate results care [1]. In this study, 58.2\% (60) participants agree with the use of technology reduces the need for nurses' physical assessment skills. About $61.1 \%$ (63) nursing students agree with physical assessment is the responsibility of medical or allied health staff. Another study helps to nurse students in the document and summarize the finding of the patients during the clinical setting. However, it also helps to increase experience in the nursing practice and increase responsibility of the nurses towards physical assessment. It is necessary for nursing students to manage-clinical issues and to enhance their clinical expertise. Physical assessment is also an important skills for nurses to improve their skills in the clinical setting [19].

\section{Conclusion}

Although nursing students were oriented and educated about physical assessment skills as an integral part of the nursing curriculum, not often practiced in clinical settings. Reliance on others and technology, ward culture, lack of influence on patient care are hurdles in performing physical assessment skills. In addition, 
reinforcing quality teaching and nursing skills are necessary to perform a comprehensive health assessment utilizing the core competencies and avoid relying too much on technology. Since, the ward takes into account the patient's need, future nurses should have a constant review of basic physical assessments to improve patients' experience of health care.

\section{Limitation}

This study was conducted during a short period of time about 3 to 4 months. Data collected only from one institute Lahore School of Nursing, The University of Lahore, Pakistan.

\section{Acknowledgement}

I would like to express my special thanks of gratitude to my teacher Mr. Muhammad Hussain as well as our principal Mr. Muhammad Afzal who gave me the golden opportunity to do this wonderful project on the topic Physical assessment skills performing hurdles among nursing students, which also helped me in doing a lot of research and I came to know about so many new things. Secondly, I would also like to thank my parents Mr. Mir Afzal and Miss. Fatima and friends who helped me a lot in finalizing this project within the limited time frame.

\section{References}

1. Rochester CL. Patient assessment and selection for pulmonary rehabilitation. Respirology. 2019;24(9):844-853.

2. Alamri MS, Almazan JU. Barriers of physical assessment skills among nursing students in Arab Peninsula. International journal of health sciences. 2018;12(3):58-66.

3. Niaz F, Hussain M, Afzal M, Gilani SA. Nursing Students Challenges at Educational and Clinical Environment at University of Lahore, Pakistan. Journal of Health, Medicine and Nursing. 2019;62:41-48.

4. Srisamang P, Kanoksil M, Luangasanatip N, Jatapai A, Day N, Peacock $\mathrm{S}$, et al. Increasing incidence of hospital-acquired and healthcare-associated bacteremia in northeast Thailand: A multicenter surveillance study. 2019;9(10):01-08.

5. Chou S-C, Venkatesh AK, Trueger NS, Pitts SR. Primary Care Office Visits For Acute Care Dropped Sharply In 2002-15, While ED Visits Increased Modestly. Health Affairs. 2019;38(2):268-275. 
6. Mitoma R, Yamauchi T. Effect of a physical assessment educational program on clinical practice. Journal of Nursing Education and Practice. 2018;8(8):96-104.

7. Zambas SI, Smythe EA, Koziol-Mclain J. The consequences of using advanced physical assessment skills in medical and surgical nursing: A hermeneutic pragmatic study. International journal of qualitative studies on health and well-being. 2016;11(1):01-13.

8. Krumanaker DT, Simms RJ, Goldberg E, Osborne TA. Dual staple cartridge for surgical stapler. Google Patents US. 2015.

9. Giddens J. Transformational leadership: What every nursing dean should know. Journal of Professional Nursing. 2018;34(2):117-21.

10. Birks M, Budden LM, Biedermann N, Park T, Chapman Y. A 'rite of passage?': Bullying experiences of nursing students in Australia. Collegian. 2018;25(1):45-50.

11. Coley SL, de Leon CFM, Ward EC, Barnes LL, Skarupski KA, Jacobs EA. Perceived discrimination and health-related qualityof-life: gender differences among older African Americans. Quality of Life Research. 2017;26(12):3449-3458.

12. Chaston JM, Newell PD, Douglas AE. Metagenome-wide association of microbial determinants of host phenotype in Drosophila melanogaster. MBio. 2014;5(5):e01631-14.

13. Sahir A, Afzal M, Hussain M, Gillani SA. The Impact of Stress on Competency Among Nursing Students in Lahore, Pakistan. Journal of Advances in Education and Philosophy.2019;3(5):200-203.

14. Battarbee RW, Lamb H, Bennett K, Edwards M, Bjune AE, Kaland PE, et al. John Birks: Pioneer in quantitative palaeoecology. 2015;25(1):03-16.

15. Batool S, Afzal M. The investigation of Determinants of Absenteeism among the Nurses of Public Hospitals. European Academic Research, 2019;6(12):6780-6805.

16. Joseph $\mathrm{M}$, Inayat $\mathrm{S}$, Hussain $\mathrm{M}$, Afzal $\mathrm{M}$, factors Influencing Nurses' Attitudes towards Information Technology in Nursing Practice.European Academic Research, 2019;7(3):1751-1769.

17. Bauer M, Fetherstonhaugh D, Winbolt M. Perceived barriers and enablers to conducting nursing assessments in residential 
aged care facilities in Victoria, Australia. Australian Journal of Advanced Nursing, The. 2018;36(2):14-22.

18. Morrell S, Ralph J, Giannotti N, Dayus D, Dennison S, Bornais J. Physical assessment skills in nursing curricula: a scoping review protocol. Journal of JBI database of systematic reviews and implementation reports. 2019;17(6):1086-1091.

19. Borji M, Tarjoman A, Nejad HT, Meymizade M, Nariman S, Safari S. Relationship between knowledge-skill and importance of physical examination for children admitted to infectious wards: examining nurses' points of view. Journal of Comprehensive Pediatrics. 2018;9(1):01-08. 